\title{
CHROMOGRANIN A IN THE OLFACTORY SYSTEM OF THE RAT
}

\author{
G. LAHR, ${ }^{*}$ C. Heiss, ${ }^{*}$ A. Mayerhofer, ${ }^{*}$ K. SChIlling, $\dagger$ R. J. Parmer, $\ddagger$ \\ D. T. O'Connort and M. GratzL* $\$$ \\ *Abteilung Anatomie und Zellbiologie der Universität Ulm, Albert-Einstein-Allee 11, \\ D-7900 Ulm, F.R.G. \\ $\nmid$ Roche Institute of Molecular Biology, Nutley, NJ 07110, U.S.A. \\ $\ddagger$ University of California and V.A. Medical Center, San Diego, CA 92161, U.S.A.
}

\begin{abstract}
The olfactory bulb of the rat contains chromogranin $\mathbf{A}$ at a similar level as the adrenal gland or the hypophysis as revealed by immunoblots. Olfactory chromogranin $\mathrm{A}$ also displays the same size as chromogranin A of endocrine cells. In the hippocampus and other brain regions, we could not detect chromogranin A by immunoblotting. In contrast, chromogranin A messenger ribonucleic acid (using S1 nuclease protection assays) was observed in all brain regions examined, including the olfactory bulb. By in situ hybridization histochemistry with a complementary ribonucleic acid probe ( 280 nucleotides), and by immunocytochemistry, chromogranin A synthesis could be localized to cell bodies of the mitral cell layer, of the external plexiform layer and of the periglomerular region of the olfactory bulb. Immunocytochemically, chromogranin A was also detected in the central projection areas of mitral and tufted cells in the primary olfactory cortex and the anterior amygdaloid area but not in the olfactory glomeruli, where the incoming olfactory nerve fibers of the primary olfactory neurons establish synaptic contacts. Taken together the data show that chromogranin A, following biosynthesis in the perikarya of the mitral and tufted cells, is specifically transported into their axonal terminals but not into their primary dendrites. We propose that the rat olfactory system could serve as a model for the study of chromogranin $A$ regulation and function in neurons.
\end{abstract}

Chromogranin A (CGA), a member of the chromogranin/secretogranin protein family, is co-stored and co-released together with the specific hormones from a variety of endocrine cells (cf. Ref. 28). Intracellular and extracellular functions of CGA have been described: CGA is a calcium-binding protein, ${ }^{21.23 .24}$ participating in calcium sequestration ${ }^{3}$ and regulation of osmotic pressure ${ }^{12}$ within chromaffin vesicles. Proteolytic processing of CGA yields peptides which inhibit secretion in a variety of endocrine cells. ${ }^{5,7,29}$ Finally, based on the physicochemical properties of CGA, it has recently been proposed that this protein is also involved in the packaging and sorting of secretory products to the regulated secretory pathway. ${ }^{9,10}$

More recently CGA immunoreactivity has also been detected in neurons of the bovine and sheep brain $^{18,20.30}$ and of the rat spinal cord. ${ }^{2,33}$ Furthermore, CGA mRNA has been found in the rat brain by Northern blotting. ${ }^{13}$

Since neurons exhibit a higher degree of functional polarization than endocrine cells, the analysis of CGA synthesis and distribution of CGA within neurons offers new perspectives to investigate the func-

§To whom correspondence should be addressed.

Abbreviations: CGA, chromogranin A; EDTA, ethylenediaminetetra-acetate; NSS, normal swine serum; nt, nucleotide; PBS, phosphate-buffered saline; SSC, sodium chloride/sodium citrate; TBS, Tris-buffered saline. tional importance of this protein. In the present study, the occurrence of CGA and its mRNA in the rat olfactory system was analysed by combined application of immunocytochemistry, immunoblotting, in situ hybridization histochemistry, and SI nuclease protection assays.

\section{EXPERIMENTAL PROCEDURES}

\section{Animals}

Adult male and female rats (Sprague-Dawley) were purchased from Charles River (Sulzfeld, F.R.G.) and housed in our vivarium under standard conditions. Animals were killed by decapitation and tissues were immediately removed and further processed as described below.

\section{Immunocytochemistry and immunobloting}

Brains, adrenals and hypophyses of three female and three male rats were immersed into Bouin's fixative for $12 \mathrm{~h}$. Subsequently they were embedded in paraffin and serial sections were cut $(5 \mu \mathrm{m})$ and mounted onto gelatin-coated glass slides. For immunocytochemistry, representative sections for various brain regions, adrenals and hypophyses were selected. Sections were deparaffinized by a run through xylene and ethanol and were permeabilized for $5 \mathrm{~min}$ with Triton X-100 in Tris-buffered saline (TBS: $50 \mathrm{mM}$ Tris, $150 \mathrm{mM} \mathrm{NaCl}, \mathrm{pH} 7.6$ ), followed by a 5 -min incubation with $0.03 \% \mathrm{H}_{2} \mathrm{O}_{2}$ in $10 \%$ methanol in TBS to block endogenous peroxidase activity. Sections were then incubated with $2 \%$ normal swine serum (NSS) in TBS for $30 \mathrm{~min}$ and subsequently incubated with a rabbit antiserum directed against the C-terminal 16 amino acid sequence of bovine CGA (YELEKVAHQLEELRRG; the terminal $Y$ enabled carrier coupling via bisdiazobenzidine ${ }^{4}$ which only slightly differs from the sequence of rat $\mathrm{CGA}^{22}$ ). The specificity of 
this antibody has been described previously. ${ }^{19}$ Different dilution steps of this antibody in $2 \%$ NSS in TBS were tested and a dilution of 1:1000 was used in all experiments reported here. Incubations with this antibody were done overnight. As second antibody, swine anti-rabbit (Dakopatts Hamburg, F.R.G.; $1: 50$ in $2 \%$ NSS in TBS, $1 \mathrm{~h}$ at room temperature) was used, followed by incubation with rabbit peroxidase-antiperoxidase (Dakopatts; $1: 100$ in 2\% NSS in TBS, $1 \mathrm{~h}$ at room temperature). Immunoreaction was visualized by a freshly prepared solution of $0.05 \%$ 3,3'-diaminobenzidine-hydrochloride (Aldrich, Milwaukee, WI, U.S.A.) and $0.01 \% \mathrm{H}_{2} \mathrm{O}_{2}$ in TBS for 5-10 min. Controls consisted of incubation with $2 \%$ NSS in TBS instead of the specific antibody and of incubation with preabsorbed antibody (with $100 \mu \mathrm{g}$ of the C-terminal 16 amino acid peptide in $1 \mathrm{ml}$ of 1:1000 diluted antiserum at room temperature for $2 \mathrm{~h}$ ). Sections were photographed using a Zeiss Photomicroscope.

For immunobloting the same CGA antiserum as for immunocytochemistry at a dilution of 1:10,000 was used. The method has been described previously in detail ${ }^{26}$ In brief, collected tissues were frozen and stored in liquid nitrogen until assay date. Sample preparation included solubilization by ultrasonic treatment, boiling for $5 \mathrm{~min}$ and centrifugation. After sodium dodecyl sulphatepolyacrylamide gel electrophoresis and blotting to nitrocellulose, immunoreactive bands were visualized by autoradiography using iodinated protein $\mathbf{A}$.

\section{cDNA and $c R N A$ probes}

The rat CGA cDNA has previously been characterized. ${ }^{22}$ In brief, the $1.6 \mathrm{~kb}$ cDNA of the protein coding region of rat CGA (an Aval-Xbal fragment) was cloned via synthetic adapters into the HindIII site of the vector pUC19.2 It was subsequently excised by EcoRI restriction, using the multiple cloning site of the vector, and cloned into Bluescribe M13(-) vector (Stratagene, La Jolla, CA, U.S.A.). This clone, referred to as rCGA MI3(-) was used to generate cRNA and cDNA anti-sense strands of the CGA mRNA.

For SI analysis single-stranded DNA was isolated after infection of the bacterial strain CMK603, containing the rCGA MI3(-) plasmid, with the helper phage $\mathrm{fl}$, according to the protocol of Promega Biotec. Uniformly labeled singlestranded cDNA probe was prepared as described. ${ }^{16,25}$ The labeled primer extended rCGA MI3(-) subclone was digested with Pvul, yielding three fragments, which were separated on $5 \%$ polyacrylamide gels $(8.3 \mathrm{M}$ urea); the 950 nucleotide (nt) fragment was isolated and re-run on a $1 \%$ agarose gel. The DNA fragment was then transferred electrophoretically to a NA45 DEAE-cellulose membrane (Schleicher \& Schül, F.R.G.) and eluted from the filter as described. ${ }^{17}$

The $950 \mathrm{nt}$ fragment yielded was used for the S1 assay. This cDNA probe contains $644 \mathrm{nt}$ of the translated and $192 \mathrm{nt}$ of the untranslated $3^{\prime}$ end from the rat CGA sequence and $114 \mathrm{nt}$ of vector sequences (see Fig. 3A).

Synthesis of ${ }^{35} \mathrm{~S}$-labeled cRNA (specific activity $7 \times 10^{8}$ c.p.m. $/ \mu \mathrm{g}$ ) for in situ hybridization was carried out according to the T3-polymerase protocol of Promega Biotec (Madison, WI, U.S.A.) using $107 \mu \mathrm{Ci}$ of $\alpha{ }^{35} \mathrm{~S} \mathrm{CTP} \mathrm{(specific}$ activity $37 \mathrm{TBq} / \mathrm{mmol}$ ) and $\mathrm{rCGA} \mathrm{M} 13(-)$ linearized with PvulI. The resulting cRNA probe contained 32 nt of the $3^{\prime}$ end and $192 \mathrm{nt}$ of the $3^{\prime}$ untranslated sequence of the rat CGA gene and $56 \mathrm{nt}$ of vector sequences (see Fig. 3A).

\section{S1 nuclease protection assay}

Total RNA was isolated by a modified guanidinium thiocyanate- $\mathrm{CsCl}$ method $^{14}$ from pooled male and female rat pituitaries, adrenal glands, hippocampi and olfactory bulbs. Total RNA $(20 \mu \mathrm{g})$ (determined photometrically) were hybridized with an excess of ${ }^{32} \mathrm{P}$-labeled cDNA probe $\left(5 \times 10^{4}\right.$ c.p.m.; specific activity $1 \times 10^{8}$ c.p.m. $\left./ \mu \mathrm{g}\right)$ in $75 \%$ formamide, $400 \mathrm{mM} \mathrm{NaCl}, 1 \mathrm{mM}$ EDTA and $20 \mathrm{mM}$ Tris- $\mathrm{HCl}\left(\mathrm{pH} \mathrm{7.4),25}\right.$ for $16 \mathrm{~h}$ at $58^{\circ} \mathrm{C}$. Hybridization was terminated by digestion with $680 \mathrm{U}$ SI nuclease (AGS, Heidelberg, F.R.G.) for $2 \mathrm{~h}$ at $37^{\circ} \mathrm{C}$. After phenol extraction and ethanol precipitation samples were separated electrophoretically on $0.3-\mathrm{mm}$-thick $5 \%$ polyacrylamide gels ( $8.3 \mathrm{M}$ urea). Gels were dried and exposed on X-ray film at $-0^{\circ} \mathrm{C}$ using intensifying screens.

\section{In situ hybridization histochemistry}

Tissues were immediately frozen and stored in liquid nitrogen. Cryostat sections (10 $\mu \mathrm{m}$; Reichert-Jung) were mounted on 3-aminopropyltriethoxysilan (Sigma) coated slides. Sections were stored until needed at $-80^{\circ} \mathrm{C}$. They were fixed in $4 \%$ paraformaldehyde-phosphate-buffered saline (PBS) for 30 min at room temperature, rinsed twice in PBS and dehydrated by an ascending series of graded alcohol.

The sections were prehybridized at $50^{\circ} \mathrm{C}$ for $3 \mathrm{~h}$ with $1 \mathrm{ml}$ hybridization solution ( $50 \%$ formamide, $0.75 \mathrm{M} \mathrm{NaCl}$, $25 \mathrm{mM}$ PIPES, pH 6.8; $25 \mathrm{mM}$ EDTA; $5 \times$ Denhardt's; $0.2 \%$ sodium dodecyl sulphate; $10 \mathrm{mM}$ dithiothreitol $250 \mu \mathrm{g} / \mathrm{ml}$ denaturated herring sperm DNA (Boehringer, Mannheim, F.R.G.); $250 \mu \mathrm{g} / \mathrm{ml}$ yeast tRNA (Boehringer) and $10 \%$ dextran sulfate). Subsequently they were hybridized at $50^{\circ} \mathrm{C}$ overnight with $5 \mathrm{ng}$ labeled $\mathrm{cRNA}$ probe (specific activity $7 \times 10^{8}$ c.p.m. $/ \mu \mathrm{g}$ ) in $150 \mu 1$ hybridization solution in a humified chamber. Controls consisted of sections pretreated with $40 \mu \mathrm{g} / \mathrm{ml}$ RNAase A (Boehringer) at $37^{\circ} \mathrm{C}$ for $30 \mathrm{~min}$ prior to hybridization. After hybridization, sections were rinsed twice in $4 \times$ sodium chloride/ sodium citrate (SSC), $20 \mathrm{mM} \beta$-mercaptoethanol and twice in $4 \times \mathrm{SSC}$ at room temperature. In order to reduce background, sections were treated for $30 \mathrm{~min}$ at $37^{\circ} \mathrm{C}$ in a buffer containing $0.5 \mathrm{M} \mathrm{NaCl}, 10 \mathrm{mM}$ Tris- $\mathrm{HCl}, \mathrm{pH} 7.5,1 \mathrm{mM}$ EDTA and $40 \mu \mathrm{g} / \mathrm{ml}$ RNAase A. They were then incubated for $30 \mathrm{~min}$ at $37^{\circ} \mathrm{C}$ in the same buffer without RNAase $A$ added and washed twice with $2 \times \mathrm{SSC}$ at $50^{\circ} \mathrm{C}$ for $15 \mathrm{~min}$. Slides were rinsed in ascending alcohol solutions, air -dried and dipped in Ilford $\mathrm{K} 2$ emulsion diluted $1: 1$ with $\mathrm{H}_{2} \mathrm{O}$. They were exposed for six weeks at $4^{\circ} \mathrm{C}$ and developed with Kodak D19 at $16^{\circ} \mathrm{C}$ for $2 \mathrm{~min}$. The sections were counterstained with Hemalaun (Mayer) and eosin.

\section{RESULTS}

\section{Immunoblotting}

The presence of CGA in various brain areas was screened by immunoblotting of tissues solubilized in sodium dodecyl sulphate. Using this technique, the only region of the brain in which CGA in amounts comparable with endocrine tissues could be found, was the olfactory bulb (Fig. 1). No CGA was observed in the hippocampus or in other regions, even when the gels were overloaded (data not shown).

In the olfactory bulb CGA displayed the same apparent molecular weight on sodium dodecyl sulphate gels of approximately $80,000-85,000$ as CGA standards prepared from the adrenal medulla and adenohypophysis. In the latter tissue extract in addition a 70,000 mol. wt CGA fragment was observed. Preabsorption of the antiserum with a synthetic peptide corresponding to the region of CGA the antiserum was raised against (the C-terminal 16-mer), abolished the staining of CGA in blots prepared from olfactory bulb and endocrine tissues. The faint 


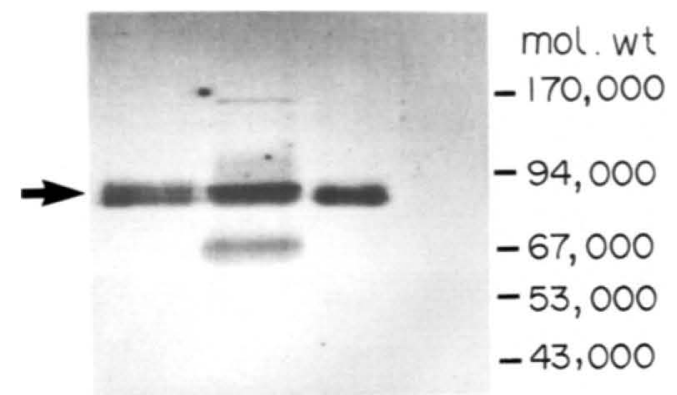

A $P \quad O \quad H$

Fig. 1. Western blot of CGA in adrenal medulla (A), pituitary $(\mathrm{P})$, olfactory bulb $(\mathrm{O})$ and hippocampus (H). The immunoblots (carried out with $100 \mu \mathrm{g}$ of protein per lane) show CGA-immunoreactive bands around $80,000-90,000 \mathrm{~mol}$. wt (arrow). An additional immunoreactive band with lower molecular weight was observed in the adenohypophysis. The gels were overloaded in order to demonstrate the absence of specific bands in hippocampus.

staining of additional high and low molecular weight bands seen in overloaded gels of tissue extracts were not affected by preabsorption.

\section{Immunocytochemistry}

Immunocytochemistry provided further information on the cellular distribution of CGA in the olfactory bulb and its primary projection areas. Weak and somewhat inconsistent CGA immunoreactivity was found in periglomerular cells and in cell bodies of tufted cells in the external plexiform layer. However, cell bodies of mitral cells showed strong immunostaining for CGA (Fig. 2A,B). In addition to the perikarya of these cells, CGA immunoreactivity was also found in the primary axonal projection areas of these cells, i.e. in the superficial half of the (superficial) plexiform cell layer (commonly referred to layer la) of the piriform cortex (Fig. 2C), as defined $^{32}$ and the anterior amygdaloid area (Fig. 2D). In contrast, the olfactory glomeruli, where the olfactory nerve fibers establish synaptic contacts with the tufted/mitral cells, were devoid of CGA immunoreactivity (Fig. 2A). Preabsorption of the antiserum or omission of the first antibody abolished all immunostaining in the olfactory system, as well as in adrenal medulla and the adenohypophysis.

\section{$S 1$ nuclease protection analysis}

A $950 \mathrm{nt}$ cDNA probe (see Experimental Procedures) was used in S1 nuclease protection assays (Fig. 3A). A $836 \mathrm{nt}$ fragment would indicate transcript of the rCGA gene containing the end of the coding region and part of the $3^{\prime}$ untranslated sequence. Indeed a protected cDNA band of $836 \mathrm{nt}$ was observed in RNA extracts of adrenals, adenohypophyses, olfactory bulbs and hippocampi demonstrating that mRNAs co-linear with the used sequence exist in the tissue analysed. However, lower amounts of CGA mRNA were found in nervous tissues compared with endocrine tissues (Fig. 3B).

\section{In situ hybridization histochemistry}

In situ hybridization revealed the cellular localization of CGA mRNA. For this purpose a short $280 \mathrm{nt}$ cRNA probe (Fig. 3A) was used to facilitate tissue penetration. In situ hybridization on frontal sections of the rostral part of the olfactory bulb is shown in Fig. 4. In mitral and tufted cells CGA mRNA could be detected, as well as in periglomerular cells (Fig. 4). In control sections, preincubated with RNAase $A$, the specific staining pattern was abolished (not shown).

\section{DISCUSSION}

Chromogranins are characteristic components of secretory vesicles of polypeptide hormone producing cells (for a recent review and further references see Ref. 28). The results of the present study indicate that CGA, the main member of the chromogranin/ secretogranin protein family, can be found in amounts comparable with endocrine tissue is the olfactory system.

The effective translation of CGA mRNA is shown by the immunocytochemical demonstration of CGA in the olfactory system. After extraction from the tissue, CGA co-migrates in sodium dodecyl sulphate gels with CGA from adrenal medulla and adenohypophysis, suggesting that it has the same molecular structure as endocrine CGA, including major posttranslational modifications. This view is further supported by the results of S1 analysis, which demonstrate that at least within the $3^{\prime}$ end of the CGA mRNA, the olfactory message is fully co-linear with the endocrine sequence. On the cellular level, CGA mRNA was localized by in situ hybridization histochemistry in the perikarya of mitral and tufted cells, as well as in periglomerular cells. The latter is a heterogeneous cell population also containing many tufted cells, ${ }^{32}$ a fact which excludes a precise identification of the CGA-positive cells in this area.

The typical structure of tufted and mitral cells (for review see Ref. 32) offered a unique opportunity to investigate the subcellular distribution of CGA. These cells, located in the periglomerular region, in the external plexiform layer and the mitral cell layer send their centrally projecting axons to the primary olfactory cortex and the amygdala. The apical (primary) dendrites of tufted and mitral cells extend to the olfactory glomeruli, where they receive input from receptor cell axons and form reciprocal dendro-dendritic synapses with receptor and periglomerular neurons. ${ }^{11}$ While CGA was clearly demonstrable by immunocytochemistry in the central projection areas of tufted and mitral neurons, i.e. the piriform cortex and the anterior amygdaloid area, no CGA immunoreactivity was found in glomerular dendrites of tufted or mitral cells.

These results on the distribution of CGA may imply that the central axonal synapses of tufted 

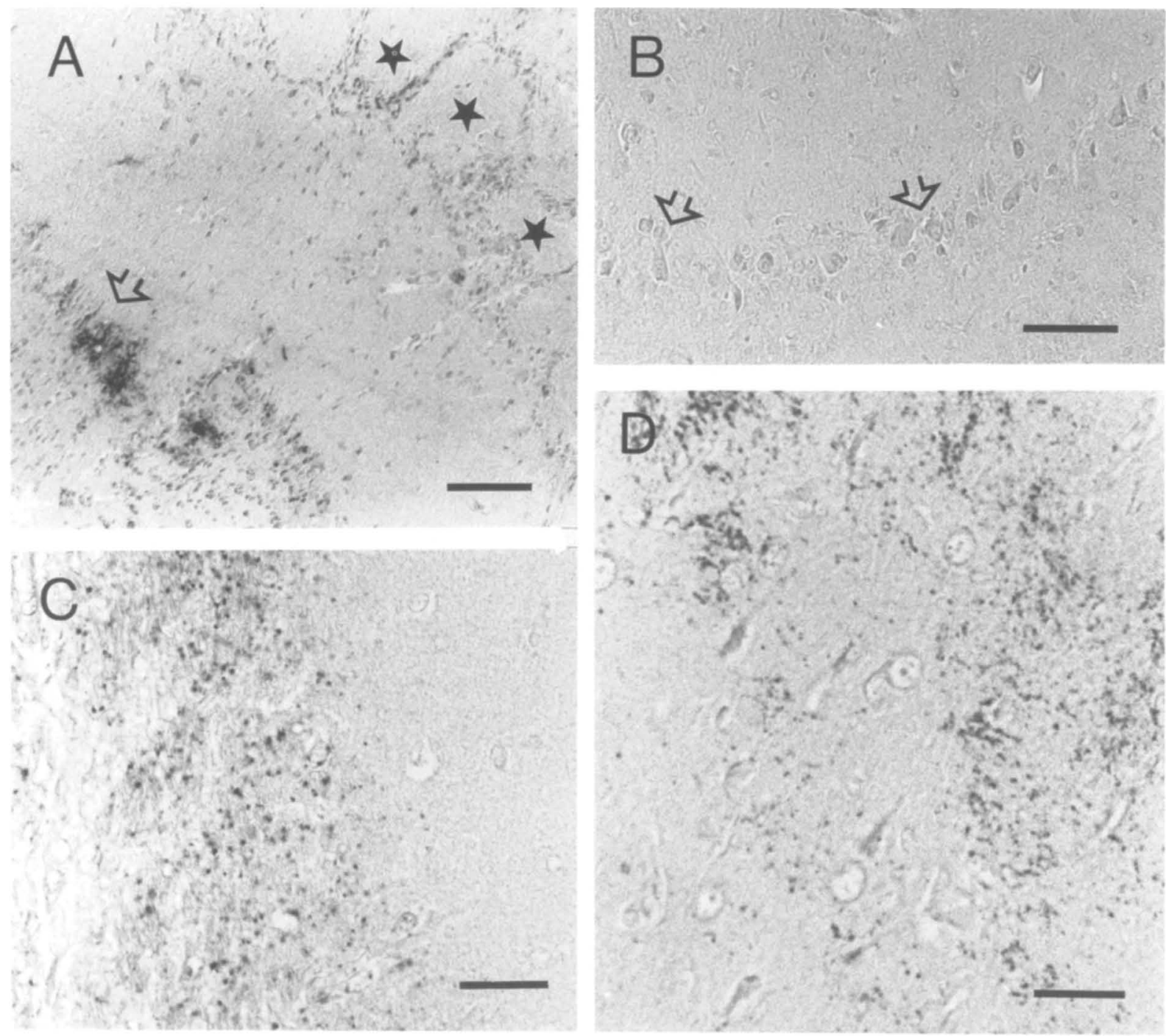

Fig. 2. CGA immunocytochemistry in olfactory bulb (A, B), primary olfactory cortex (piriform cortex) (C), and anterior amygdaloid area (D). In A glomeruli are marked with stars. Arrow points at mitral cells which are also shown in B. In C immunoreaction is confined to the superficial half of the (superficial) plexiform layer but is absent in the adjacent lateral olfactory tract (left) and the soma layer (right). (D) The anterior amygdaloid area. Note: staining of cell bodies in A and B but not in C and D. Scale bars $=75 \mu \mathrm{m}(\mathrm{A}) ; 50 \mu \mathrm{m}(\mathrm{B}) ; 20 \mu \mathrm{m}(\mathrm{B}$ and $\mathrm{C})$.

and/or mitral cells differ from the dendritic synapses as far as the amount of CGA is concerned. One could also speculate that CGA is found only in "axonal" secretory vesicles and may be involved in the differential packaging of neurotransmitters into axonal vesicles. Such a function has recently been proposed for CGA, based on its physicochemical properties. ${ }^{910}$ Presence of CGA in axonal endings has previously been reported in motoneurons of the spinal cord. ${ }^{2,33}$

However, the differences in axonal versus dendritic CGA content do not exclude that CGA may be packaged in both vesicles, those transported to the axon terminals, and those shipped to the glomerular dendrites. Dendritic CGA might undergo modifcation rendering it unrecognizable by our antibody.
It can be anticipated that such modifications might also affect the physiological function of CGA. The presence of CGA mRNA revealed by $\mathrm{S} 1$ nuclease protection assays and the absence of CGA in immunoblots of the rat hippocampus, shown in the present study, might point to such a possibility. However, presently it cannot be ruled out that, within the hippocampus as opposed to the olfactory system, the CGA mRNA is translated only in small amounts. The latter interpretation is supported by the finding that within the hippocampus of the sheep, CGA can be found in immunoblots. ${ }^{30}$ Recently minute amounts of CGA have been detected in various regions of the bovine brain. ${ }^{15}$

The fact that CGA was detected in the present study within the axonal endings of the secondary 
A

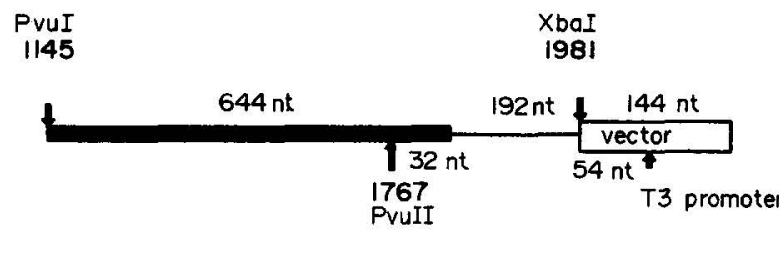

$950 \mathrm{nt}$

CDNA

rCGA $\mathrm{MI3}(-)$

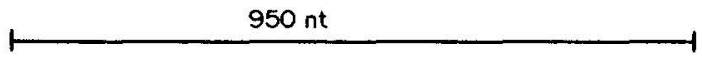

cDNA probe

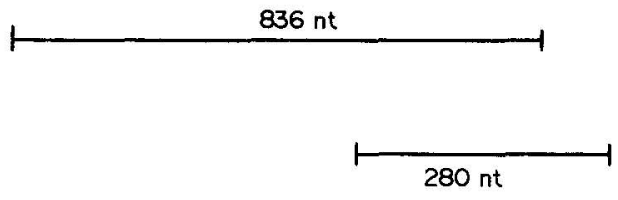

protected cDNA

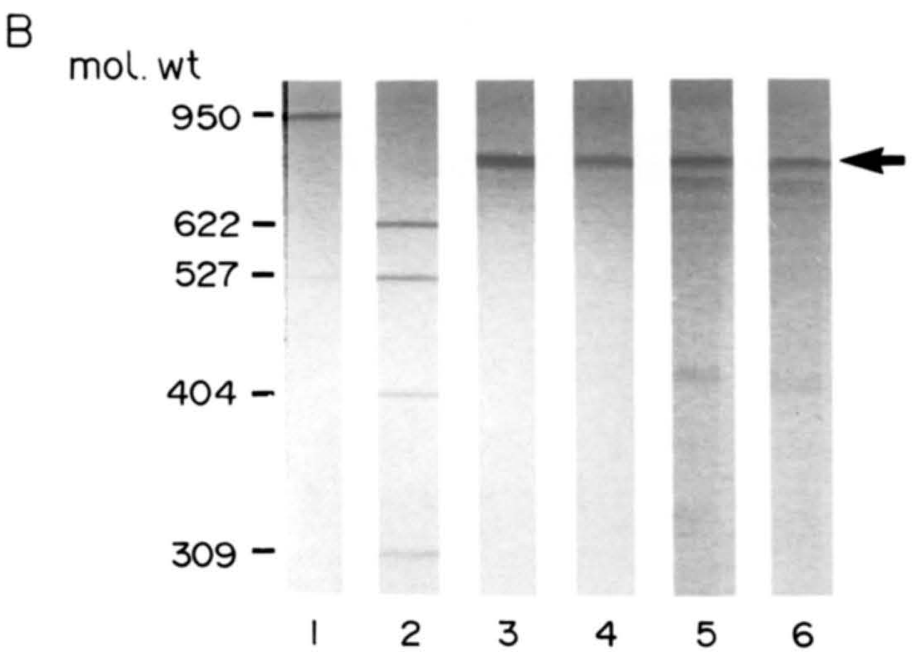

Fig. 3. S1 nuclease protection analysis of extracted mRNA of rat tissues. For hybridization, a single-stranded anti-sense DNA probe derived from rCGA M13(-) clone, which is a XbaI-PvuI subclone of $950 \mathrm{nt}$ (see Experimental Procedures), was used. (A) Localization of the single-stranded cDNA probe relative to the $3^{\prime}$ end of the rCGA. Restriction sites are indicated. Bold numbers above and below the restriction sites mark the positions of the rCGA nucleotide sequence. ${ }^{22}$ The cDNA probe synthesized (see Experimental Procedures) and the fragment protected from S1 nuclease are given as thin lines. All sizes of fragments are given above the lines with the exception of the nucleotides corresponding to the cRNA probe. The in vitro transcription start site is indicated by the T3 promoter. The thick line corresponds to the translated part of the $3^{\prime}$ end of the rCGA transcript $(644 \mathrm{nt})$, while the thin line (192 nt) corresponds to the $3^{\prime}$ untranslated sequence up to the internal XbaI restriction site. The box corresponds to vector sequences. The line at the bottom shows the size of the cRNA probe synthesized (see Experimental Procedures). (B) In lanes 3-6 the ${ }^{32}$ P-labeled cDNA probe defined in A served as hybridization probe for $20 \mu \mathrm{g}$ total RNA each. (Lane 3) adrenal medulla; (lane 4) pituitary; (lane 5) olfactory bulb; (lane 6) hippocampus. As a size marker, HpaII digested pBR322 was applied to lane 2. The sizes are indicated on the left side. The $950 \mathrm{nt}$ band in lane 1 represents undigested probe containing flanking Bluescribe $\mathrm{M} 13(-)$ vector sequences, while the protected $836 \mathrm{nt}$ fragment (arrow) indicates rCGA mRNA in the tissue analysed. Duration of film exposure was $3 \mathrm{~h}$ for lanes $1-4$ and $16 \mathrm{~h}$ for lanes 5 and 6 . Note: this indicates that endocrine tissue contains more CGA mRNA than nervous tissues.

neurons of the rat olfactory system may indicate a specific role of CGA in olfactory signalling. For example, CGA could be involved in intravesicular calcium sequestration, ${ }^{3,21,23,24}$ and CGA derived peptides may act as hormones/transmitters. ${ }^{5,7,29}$ Thus, CGA may participate in the regulation of intraterminal calcium and/or modulation of the release of the hitherto unidentified transmitter(s) (cf.
Ref. 11) used by tufted/mitral cells at their axonal (central) synapses.

\section{CONCLUSION}

Our results support previous studies on the distribution of CGA-immunoreactive material in the bovine and sheep brain ${ }^{15,18,30}$ and confirm Northern 


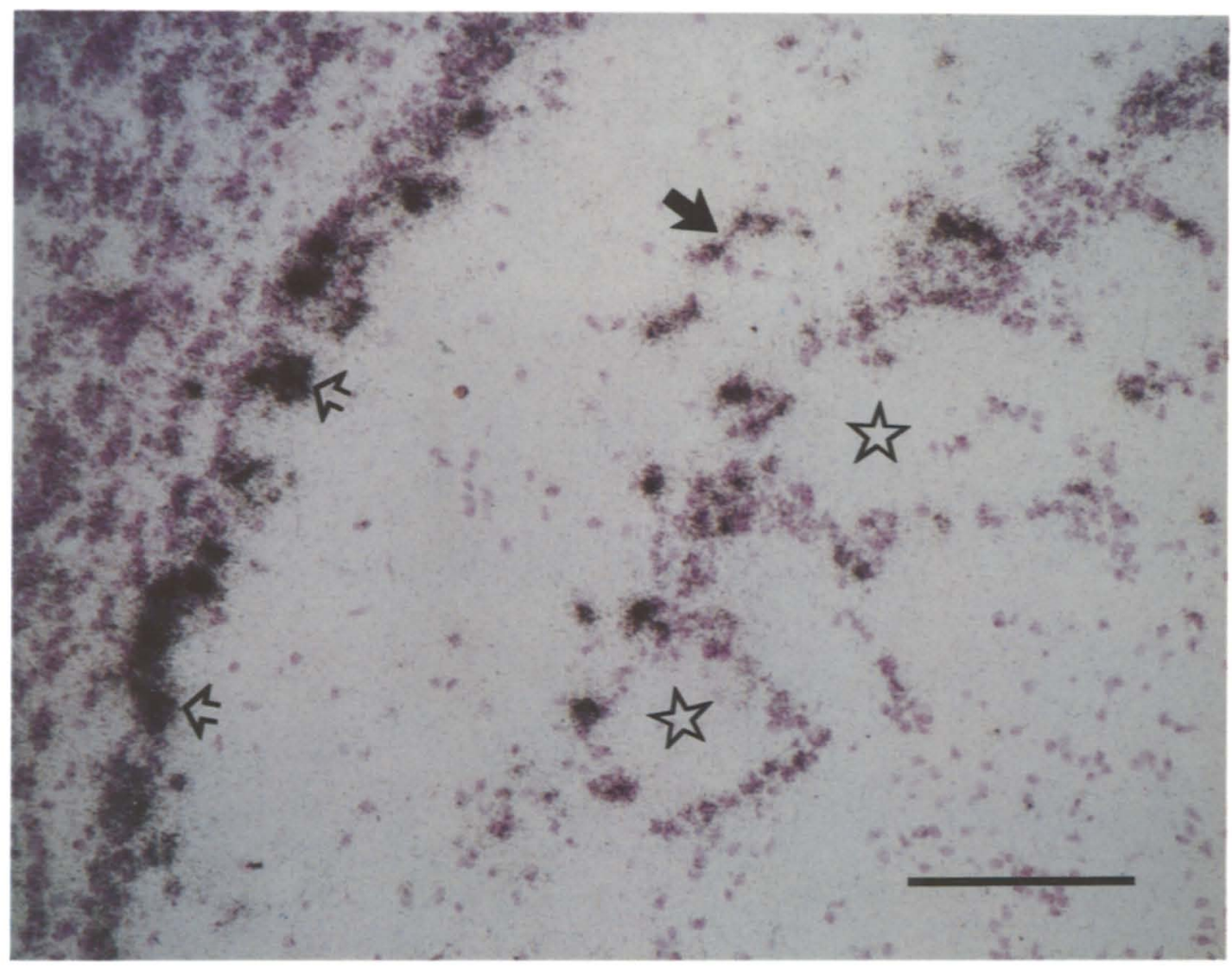

Fig. 4. In situ hybridization of olfactory tissue sections. Mitral cells (open arrows) and the heterogeneous group of periglomerular cells adjacent to the olfactory glomeruli (two of which are marked with stars) contain rCGA-specific cRNA. Groups of tufted cells (filled arrow) in the external plexiform,layer, which is situated between the olfactory glomeruli and the mitral cell layer (open arrows) are also labeled. Also compare Fig. 2A. The autoradiographic exposure time was 42 days. Scale bar $=100 \mu \mathrm{m}$.

blot analyses on the occurrence of CGA mRNA in the rat brain. ${ }^{13}$ The Purkinje cells of the cerebellum, which are comparable with the mitral/tufted cells in that they are the only output generating systems of the cerebellum, also contain CGA in the sheep ${ }^{30}$ and the cow. ${ }^{18}$ In the human, only chromogranin $B$ (secretogranin I) was expressed in the Purkinje cells. ${ }^{27}$ To our knowledge the presence of chromogranins in axons and/or dendrites of Purkinje cells, has not been investigated.

Recently the distribution of mRNA of chromogranin B (secretogranin I) has been analysed in the rat brain. ${ }^{8}$ Here we report the occurrence and distribution of CGA and its mRNA in the olfactory system. The anatomical structure of this system is well known (for review see Ref. 32) and this system is readily accessible to experimental manipulation (see e.g. Refs 1, 6). Therefore, we propose that the olfactory system of the rat can be used as a unique model for the study of the regulation of CGA synthesis, intracellular sorting, and function.

Acknowledgements - The authors thank Mrs S. Bucher and I. Urban for expert technical assistance. This work was supported by "starting grants" to Ch. H. and A. M. from the University of Ulm and by Forschungsschwerpunkt 32 of the State of Baden Württemberg.

\section{REFERENCES}

1. Baker H., Towle A. C. and Margolis F. L. (1988) Differential afferent regulation of dopaminergic and GABAergic neurons in the mouse main olfactory bulb. Brain Res. 450, 69-80.

2. Bööj S., Goldstein M., Fischer-Colbrie R. and Dahlström A. (1989) Calcitonin gene-related peptide and chromogranin A. Presence and intra-axonal transport in lumbar motor neurons in the rat, a comparison with synaptic vesicle antigens in immunohistochemical studies. Neuroscience 30, 479-501.

3. Bulenda D. and Gratzl M. (1985) Matrix free $\mathrm{Ca}^{2+}$ in isolated chromaffin vesicles. Biochemistry 24, 7760-7765.

4. Doolittle R. F. (1986) Of Urfs and Orfs: a Primer on How to Analyze Derived Amino Acid Sequences. University Science Books, Mill Valley, California.

5. Efendic S., Tatemoto K., Mutt V., Quan C., Chang D. and Östenson C. G. (1987) Pancreastatin and islet hormone release. Proc. natn. Acad. Sci. U.S.A. 84, 7257-7260. 
6. Ehrlich M. E., Grillo M., Joh T. H., Margolis F. L. and Baker H. (1990) Transneuronal regulation of neuronal specific gene expression in the mouse olfactory bulb. Molec. Brain Res. 7, 115-122.

7. Fasciotto B. H., Gorr S. U., DeFranco D. J., Levine M. A. and Cohn D. V. (1989) Pancreastatin, a presumed product of chromogranin A (secretory protein-I) processing inhibits secretion from porcine parathyroid cells in culture. Endocrinology 125, 1614-1622.

8. Forss-Petter S., Danielson P., Battenberg E., Bloom F. and Sutcliffe J. G. (1989) Nucleotide sequence and cellular distribution of rat chromogranin B (secretogranin 1 ) mRNA in the neuroendocrine system. $J$. molec. Neurosci. 1, 63-75.

9. Gerdes H. H., Rosa P., Phillips E., Baeuerle P. A., Frank R., Argos P. and Huttner W. B. (1989) The primary structure of human secretogranin II, a widespread tyrosine-sulfated secretory granule protein that exhibits low $\mathrm{pH}$ and calcium induced aggregation. J. biol. Chem. 264, 12,009-12,015.

10. Gorr S. U., Shioi J. and Cohn D. (1989) Interaction of calcium with porcine adrenal chromogranin A (secretory protein-I) and chromogranin B (secretogranin I). Am. J. Physiol. 257, E247-E254.

11. Halász N. and Shepherd G. M. (1983) Neurochemistry of the vertebrate olfactory bulb. Neuroscience 10, 579-619.

12. Helle K. B., Reed R. K., Pihl K. E. and Serck-Hanssen G. (1985) Osmotic properties of the chromogranins and relation to osmotic pressure in catecholamine storage granules. Acta physiol. scand. 123, 21-32.

13. Iacangelo A. L., Okayama H. and Eiden L. E. (1988) Primary structure of rat chromogranin A and distribution of its mRNA. Fedn Eur. biochem. Socs Lett. 227, 115-121.

14. Kaplan B. B., Bernstein S. L. and Gioio A. E. (1979) An improved method for the rapid isolation of bovine ribonucleic acid. Biochem. J. 183, 181-184.

15. Kawakubo A., Takasuki K., Yoneda M., Kurokawa M., Suzuki A., Semba R. and Kato K. (1989) Highly sensitive enzyme immunoassay for bovine chromogranin A: application for studies of regional distribution in bovine central nervous system. $J$. molec. Neurosci. 1, 215-223.

16. Ley T. J., Anagnou N. P., Pepe G. and Nienhuis A. W. (1982) RNA processing errors in patients with $\beta$-thalassemia. Proc. natn. Acad. Sci. U.S.A. 79, 4775-4779.

17. Lizardi P. M., Binder R. and Short S. A. (1984) Preparative isolation of DNA and biologically active mRNA from diethylaminoethyl membrane. Gene Analyt. Tech. 1, 33-39.

18. Nolan J. A., Trojanowski J. Q. and Hogue-Angeletti R. (1985) Neurons and neuroendocrine cells contain chromogranin: detection of the molecule in normal bovine tissues by immunochemical and immunohistochemical methods. J. Histochem. Cytochem. 33, 791-798.

19. O'Connor D. T. and Takiyyuddin M. A. (1988) Synthetic peptide epitopes: clues to the structure, conformation, distribution and processing of chromogranin A. Clin. Res. 36, 187a.

20. O'Connor D. T. and Frigon R. P. (1984) Chromogranin A, the major catecholamine storage vesicle soluble protein. Multiple size forms, subcellular storage and regional distribution in chromaffin and nervous tissue elucidated by radioimmunoassay. J. biol. Chem. 259, 3237-3247.

21. O'Connor D. T., Parmer R. J. and Deftos L. J. (1984) Chromogranin A: studies in the endocrine system. Trans. Assoc. Am. Physicians $97,242-250$.

22. Parmer R. J., Koop A. H., Handa M. T. and O'Connor D. T. (1989) Molecular cloning of chromogranin A from rat pheochromocytoma cells. Hypertension 14, 435-444.

23. Reiffen F. U. and Gratzl M. (1986) Chromogranins, widespread in endocrine and nervous tissue, bind $\mathrm{Ca}^{2+}$. Fedn Eur. biochem. Socs Lett. 195, 327-330.

24. Reiffen F. U. and Gratzl M. (1986) $\mathrm{Ca}^{2+}$ binding to chromaffin vesicle matrix proteins: effect of $\mathrm{pH}, \mathrm{Mg}^{2+}$ and ionic strength. Biochemistry 25, $4402-4406$.

25. Ruppert C., Goldowith D. and Wille W. (1986) Proto-oncogene c-myc is expressed in cerebellar neurons at different development stages. Eur. molec. Biol. Org. J. 5, 1897-1901.

26. Schilling $K$. and Aletsee-Ufrecht M. C. (1989) An immunoblot assay for the simultaneous quantification of several antigens. Analyt. Biochem. 177, 203-206.

27. Schmid K. W., Weiler R., Xu R. W., Hogue-Angeletti R., Fischer-Colbrie R. and Winkler H. (1989) An immunological study on chromogranin $\mathrm{A}$ and $\mathrm{B}$ in human endocrine and nervous tissues. Histochem. J. 21, 365-373.

28. Simon J. P. and Aunis D. (1989) Biochemistry of the chromogranin A protein family. Biochem. J. $262,1-13$.

29. Simon J. P., Bader M. F. and Aunis D. (1988) Secretion from chromaffin cells is controlled by chromogranin A-derived peptides. Proc. natn. Acad. Sci. U.S.A. 85, 1712-1716.

30. Somogyi P., Hodgson A. J., DePotter R. W., Fischer-Colbrie R., Schober M., Winkler H. and Chubb I. W. (1984) Chromogranin immunoreactivity in the central nervous system: immunochemical characterization, distribution and relationship to catecholamine and enkephalin pathways. Brain Res. Rev. 8, 193-230.

31. Sternberger L. (1986) Immunocytochemistry, 3rd edn. John Wiley, New York.

32. Switzer R. C., De Olmos J. and Heimer L. (1985) Olfactory System. In The Rat Nervous System (ed. Paxinos G.), Vol. 1, pp. 1-36. Academic Press, Sydney.

33. Volknandt W., Schober M., Fischer-Colbrie R., Zimmermann H. and Winkler H. (1987) Cholinergic nerve terminals in the rat diaphragm are chromogranin A immunoreactive. Neurosci. Lett. 81, 241-244. 